\title{
Observations of Mudpuppy (Necturus maculosus) bycatch in a recreational ice fishery in northern Ontario
}

\author{
Robert J. Lennox ${ }^{1, ~ *}$, William M. Twardek ${ }^{1}$, and Steven J. CoOKe ${ }^{1}$ \\ ${ }^{1}$ Fish Ecology and Conservation Physiology Laboratory, Department of Biology, Carleton University, 1125 Colonel \\ By Drive, Ottawa, Ontario K1S 5B6 Canada \\ ${ }^{*}$ Corresponding author: robertlennox9@gmail.com
}

Lennox, R.J., W.D. Twardek, and S.J. Cooke. 2018. Observations of Mudpuppy (Necturus maculosus) bycatch in a recreational ice fishery in northern Ontario. Canadian Field-Naturalist 132(1): 61-66. https://doi.org/10. 22621/cfn.v132i1.2040

\begin{abstract}
Bycatch in fisheries is a well-explored topic, although less so in recreational fisheries. We encountered frequent bycatch of Mudpuppy (Necturus maculosus), a neotenic aquatic salamander that is active in winter, in passively baited ice-fishing gear targetting teleost fishes. We noted hook location in Mudpuppies captured by two hook types: J-hooks and circle hooks. Our prediction was that circle hooks would reduce the frequency of deep hooking of Mudpuppies, which is often cited as an important predictor of post-release mortality in fishes. We found no difference in the frequency of deep hooking of Mudpuppies captured by circle or J-hooks, although, in a subset of Mudpuppies ( $n=13$ ) held for $24 \mathrm{~h}$ after capture, one death occurred ( $8 \%)$. Further research may be necessary to determine whether deeply hooked Mudpuppies can pass or shed hooks and survive beyond the 24-h period we monitored. However, our findings suggest that anglers and managers should consider refinements to handling practices for Mudpuppies captured as bycatch, because they are likely to survive if handled cautiously. These results, which are among the first describing non-fish bycatch in recreational fisheries, call for managers and anglers who encounter Mudpuppies during recreational fishing to seek more information and educational opportunities to improve the fate of this important component of temperate freshwater ecosystems and ecological indicator species that is incidentally captured by ice fishing.
\end{abstract}

Key words: Mudpuppy; Necturus maculosus; fisheries management; winter biology; circle hook

\section{Introduction}

In many nations, recreational fisheries are more economically valuable than the commercial sector, with billions of fish captured annually by recreational angling (Cooke and Cowx 2004; Tufts et al. 2015). The methods used to target fish in recreational fisheries tend to be more limited than in commercial fisheries, as fishing is predominantly conducted by hook and line with various lures, flies, or baits used to attract fish to hooks. Although the gear selected by anglers is often chosen to suit a specific target species or group of species (Pope et al. 2016), the incidental bycatch of non-target fishes can be considerable, as is the potential for capture of non-target taxa. Freshwater bycatch is an emerging conservation challenge (Raby et al. 2011; Stoot et al. 2013), although the literature has been focussed predominantly on commercial fishing (e.g., Silva and Best 1996; Bell and Lyle 2016).

Little research has been carried out on ice fishing, a type of recreational fishery popular at higher latitudes (Deroba et al. 2007; Twardek et al. 2018). Ice fishing involves drilling or cutting through ice to gain access to winter-active fish. Typically, a hook is baited with live or cut bait and set using rod or passive lines at an appro- priate depth for the targetted game fish. Most jurisdictions allow for more than one line per angler at any one time and this, combined with water conditions and hole size, make observation difficult, hindering angler-mediated selectivity.

Understanding the impact of fishing practices on captured species is necessary to achieve sustainable fisheries. Best practices in recreational fisheries can be implemented to minimize impacts on captured animals (Brownscombe et al. 2017). This includes appropriate selection of terminal tackle (i.e., hooks), which is often regulated by management authorities (Schill and Scarpella 1997; Cerdà et al. 2010). Circle hooks have been marketed as an effective tool for reducing mortality of captured fish by minimizing deep-hooking (Serafy et al. 2012). The circle hook is designed with the point oriented $90^{\circ}$ to the shank so that it rotates when ingested by an animal and lodges more frequently in the lips rather than the gullet. Circle hooks are used in both commercial and recreational fisheries to minimize bycatch of nontarget fish as well as other taxa such as marine turtles (Cooke and Suski 2004; Sales et al. 2010).

Mudpuppy (Necturus maculosus) is a species of neotenic freshwater salamander native to North American 
lakes and rivers. Mudpuppy activity is highest in cold temperatures, and they feed on many of the same prey items as game fish (Shoop and Gunning 1967; Beattie et al. 2017). Although not listed as at risk in most jurisdictions, including Canada (SARA Registry 2018), declines in population levels have been reported (Mifsud 2014; Harding and Mifsud 2017), and several United States agencies have granted them various conservation statuses (Matson 2005). Mudpuppies are long-lived (Bonin et al. 1995) and late to mature (Bishop 1943), likely making them sensitive to adult mortality (Congdon et al. 1994). Siltation and chemical pollutants (Bonin et al. 1995; Matson 1998, 2005) are likely chronic threats to local populations, and bycatch in recreational ice fisheries is a recognized but poorly quantified risk.

Capture of Mudpuppies by ice fishing is incidental in the winter, when Walleye (Sander vitreus) and other teleosts are targetted with baited hooks, often on passively set lines near the substrate where Mudpuppies are most active (Craig et al. 2015). Mudpuppies may ingest hooks on set lines, resulting in deep-hooking, a topic that has been extensively explored for teleost species and consistently demonstrated to be one of the most important predictors of post-release mortality in recreational catch-and-release fisheries (Muoneke and Childress 1994). Although Mudpuppies may be captured by recreational anglers, their presence in lakes may not be well known among anglers, and some anglers may cull them out of spite or misunderstanding of their ecological role (Craig et al. 2015). Retrieval, handling, unhooking, and release of Mudpuppies may be inconsistent among anglers with a poor understanding of the species biology, particularly without guidelines regarding best practices. Moreover, it is uncertain whether Mudpuppies captured and released through ice holes are likely to survive or if the retrieval, exposure to air and cold, handling, or hooking damage will lead to mortality.

In this study, we compare the hooking of Mudpuppies captured on two terminal hooking gears, circle hooks and J-hooks, and quantify the short-term survival of Mudpuppies released following recreational angling.

\section{Methods}

Mudpuppies were captured as bycatch (Figure 1) between 2100 and 0700 while fishing for Walleye on South Bay, Lake Nipissing, Ontario, Canada $\left(46.2730^{\circ} \mathrm{N}\right.$, $79.8022^{\circ} \mathrm{W}$ ). Between 10 January and 3 February 2017 , we set passive lines using tip-ups, which have a springloaded mechanism for signalling the hooking of a fish that has struck a baited hook passively suspended beneath the ice. The sensitivity of these devices is set to detect the presence of larger teleost fishes that pull on the spool with more force than Mudpuppies; thus, the reliability of the flag signal to detect Mudpuppies was poor. Tip-ups were set 15-30 cm off bottom (depth
7-8 $\mathrm{m}$ ) with both circle and J-style hooks (Octopus 4 and Octopus circle 4; Gamakatsu, Tacoma, Washington, USA) baited with live shiners (e.g., Notropis spp.) and weighted with a 7-g lead sinker. Water temperature remained at $4^{\circ} \mathrm{C}$ in the hypolimnion layer where Mudpuppies were captured, while ambient air temperature varied from $-19.4^{\circ} \mathrm{C}$ to $3.3^{\circ} \mathrm{C}$ during the study period.

Mudpuppies were landed by angling in approximately $20 \mathrm{~s}$, with little variation among individuals. For each Mudpuppy that was captured, we estimated the length (to the nearest centimetre) and characterized the anatomical hooking location. Following practices of local anglers who captured Mudpuppies, we removed the hooks from individuals hooked in the lip and cut the lines on all deeply hooked Mudpuppies. The observation period resulted in about $45 \mathrm{~s}$ of air exposure. A subset of 13 Mudpuppies was transferred into conical holding pens (volume $=0.5 \mathrm{~m}^{3}$ ) suspended beneath the ice at the depth at which the Mudpuppies were captured $(\sim 7-8 \mathrm{~m})$. Nets were emptied after $24 \mathrm{~h}$ to determine Mudpuppy survival. No net held more than three Mudpuppies during an overnight holding period.

Because of this small sample size, statistical analysis was not feasible to determine drivers of mortality; thus, we simply provide accounts of the mortality. A $\chi^{2}$ test was used to evaluate potential differences in hooking locations of Mudpuppies caught by circle and J-style hooks using the chisq.test function in $\mathrm{R}$ ( $\mathrm{R}$ Core Team 2017).

\section{Results}

During an estimated 3655 rod-h on Lake Nipissing using both passive and active lines, we captured 80 Mudpuppies, $\sim 0.02 /$ rod-h. Although not quantified, most Mudpuppies were captured at night and on passive baited lines. For our study, we captured 48 Mudpuppies on passively set ice fishing lines. One of these was captured by a dead-stick (i.e., ice fishing rod passively suspending a baited lure) with a treble hook and was excluded from further description because of low sample size with this gear; however, this individual was hooked in the outer lip and survived. We were unable to measure most Mudpuppies because they responded to capture and handling by curling into a small ball. However, we estimate that most were $\sim 18-22 \mathrm{~cm}$ long. At these sizes, they are not likely to be fully mature (McDaniel et al. 2009).

Only four of the 47 Mudpuppies (9\%) were shallow hooked in the lips; the remainder had ingested the baited hook, which we assumed was lodged inside the stomach (Figure 2). There was no difference in the incidence of deep hooking with circle hooks compared with J-hooks $\left(\chi_{1}^{2}<0.01, P=1.00\right)$. Despite the high frequency of deep hooking, only one of 13 Mudpuppies died (8\%) during the 24-h holding. This individual was captured using a circle hook and ingested the hook. All other Mudpuppies were released back into the water. 


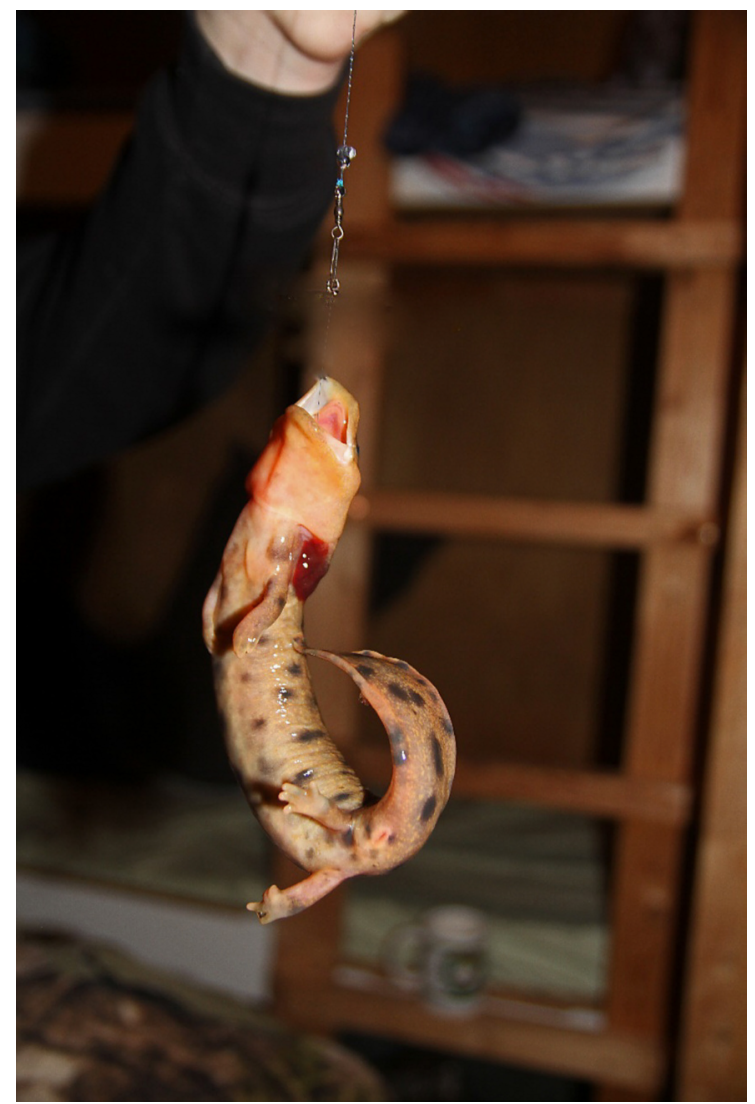

Figure 1. Mudpuppy (Necturus maculosus) captured by ice fishing in Lake Nipissing, Ontario, Canada. This individual was not included in the study, but is representative of the type of capture event investigated. Photo: W.M. Twardek.

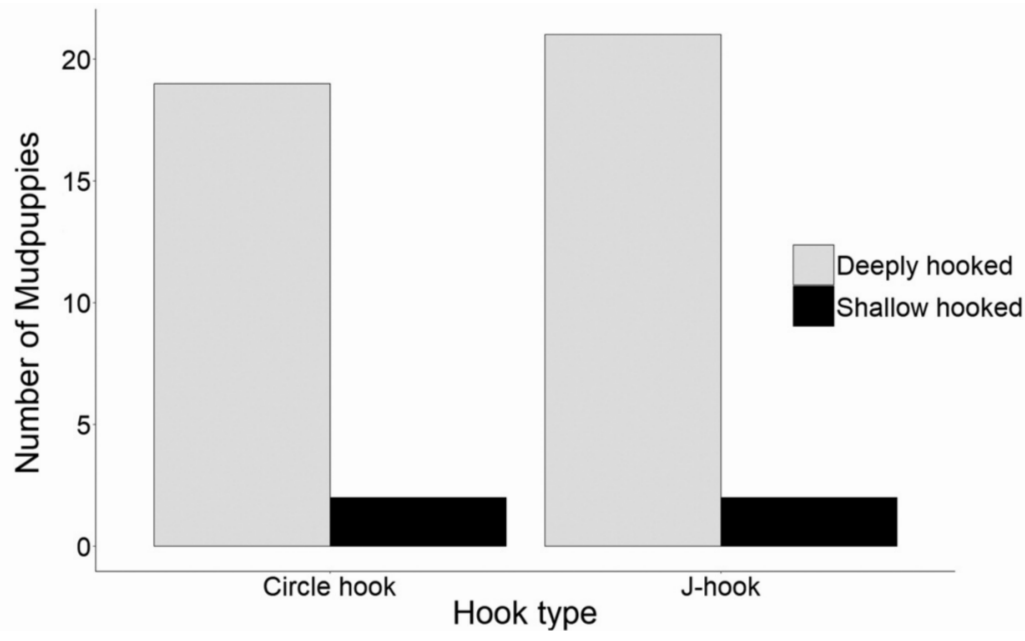

FIGURE 2. Hooking locations, characterized visually, and hook types observed to capture Mudpuppies (Necturus maculosus) while ice fishing in Lake Nipissing, Ontario, Canada. 


\section{Discussion}

This was an opportunistic study of Mudpuppies conducted during an ice fishing project targetting Walleye, and sample sizes were small. However, it is clear that a large number of Mudpuppies may be captured and released by recreational anglers in winter ice fisheries. Our findings present the first evidence that Mudpuppies survive encounters with recreational anglers even when deeply hooked and call for additional research on the extent and impact of recreational bycatch of Mudpuppies.

Encounters with anglers in the fishery suggested that they were unfamiliar with Mudpuppies and unaware of their presence in Lake Nipissing, which is a prominent ice fishing destination. We observed some anglers capturing Mudpuppies and jettisoning them onto the ice to inspect them before we suggested that they cut the line and release them down the hole. We did not study the effect of prolonged exposure to sub-zero air temperatures, but given that Mudpuppies respire by lungs, gills, and through the epithelium, these external organs (gills and skin) may be sensitive to freezing temperatures and the formation of ice crystals on these structures could cause permanent damage. Additional research is necessary to determine the effect of cold air exposure, but presumably the most risk-averse and recommended behaviour would be for anglers to rapidly unhook (or cut) Mudpuppies from the line and release them back into the water with limited air exposure. This is consistent with guidelines for fish captured either incidentally or intentionally that are destined to be released (Cook et al. 2015), but could be more urgent at lower temperatures.

Relative to most fish captured by hook and line, the observed rates of deep hooking in Mudpuppies were high (Hühn and Arlinghaus 2011). This is likely related to the feeding ecology of Mudpuppies that use interlocked lips to suction-feed on prey (Gans and Nussbaum 1992). Some anglers targetting Walleye or other teleosts may insist on removing hooks from deeply hooked Mudpuppies; however, evidence from teleosts consistently suggests that hook removal from deeply hooked animals results in organ injury and bleeding, whereas cutting the line may allow the animal to pass or shed the hook (e.g., Weltersbach et al. 2016). Although we did not experiment with different hook removal techniques, our results suggest that cutting the line and releasing deeply hooked Mudpuppies results in infrequent short-term mortality. Further research may investigate whether survival is significantly different for hook removal compared with cutting the line. However, removing the hook from a deeply hooked Mudpuppy would most likely be fatal; thus, we only ever cut the line. Whether Mudpuppies can successfully expel a hook could be further studied using longer-term observations of survival or radiography (see Weltersbach et al. 2016).
In this study, we found that circle hooks did not reduce the frequency of deep-hooking Mudpuppies and, therefore, are not necessarily an effective means of improving the fate of Mudpuppies captured by anglers. However, larger sized hooks may preclude swallowing by Mudpuppies and their potential could be further investigated alongside a Walleye fishery to compare catch rates of Walleye and critical hooking rates of Mudpuppy. Observed high rates of deep-hooking are likely similar to those naturally occurring in the fishery but may be because of low sensitivity of the tip-ups, which were calibrated for detecting bites from Walleye.

Mudpuppies are an important component of freshwater ecosystems and are long-lived and late maturing, life history traits that make them vulnerable to overexploitation as bycatch in recreational fisheries (Matson 2005; Craig et al. 2015). Their presence in freshwater systems is a good indicator of ecosystem health (Craig et al. 2015), and their conservation should be a priority for those who work for natural resource management agencies, including fisheries managers, to ensure that they are covered in fishing regulations. Given that we frequently captured Mudpuppies while fishing for Walleye, a better understanding of the responses of Mudpuppies to angling may be necessary to provide recommendations to anglers who capture them, dispel myths about their negative interactions with gamefishes, and promote best handling practices so that Mudpuppies can be released from ice fisheries alive (Craig et al. 2015).

\section{Author Contributions}

Writing - Original Draft: R.J.L, W.M.T.; Writing Review \& Editing: R.J.L., W.M.T., S.J.C.; Conceptualization: R.J.L., W.M.T., S.J.C.; Investigation: R.J.L., W.M.T.; Methodology: R.J.L., W.M.T.; Formal Analysis: R.J.L.; Funding Acquisition: S.J.C.

\section{Acknowledgements}

This research was conducted in partnership with the Ontario Ministry of Natural Resources and Forestry. The Carleton University Animal Care Committee approved research protocol $\# 106247$ for this project. Mudpuppies were unexpected bycatch that presented an opportunity to share our findings in this manner. We thank M. Young and Lake Nipissing Ice Fishing Charters for their accommodation during our stay in North Bay. D. Algera, C. Davis, S. Eldøy, M. Lawrence, $\mathrm{J}$. Monaghan, and A. Zolderdo provided assistance in the field. N. Cairns provided input on the ecology of Mudpuppies relevant to this manuscript.

\section{Literature Cited}

Beattie, A.M., M.R. Whiles, and P.W. Willink. 2017. Diets, population structure, and seasonal activity patterns of mudpuppies (Necturus maculosus) in an urban, Great Lakes coastal habitat. Journal of Great Lakes Research 43: 132143. https://doi.org/10.1016/j.jglr.2016.11.004 
Bell, J., and J. Lyle. 2016. Post-capture survival and implications for by-catch in a multi-species coastal gillnet fishery. PLoS One 11:e0166632. https://doi.org/10.1371/journal. pone.0166632

Bishop, S.C. 1943. Handbook of Salamanders: the Salamanders of the United States, of Canada, and of Lower California (Volume 3). Cornell University Press, Ithaca, New York, USA.

Bonin, J., J.L. DesGranges, C.A. Bishop, J. Rodrigue, A. Gendron, and J.E. Elliott. 1995. Comparative study of contaminants in the mudpuppy (Amphibia) and the common snapping turtle (Reptilia), St. Lawrence River, Canada. Archives of Environmental Contamination and Toxicology 28: 184-194. https://doi.org/10.1007/BF00217615

Brownscombe, J.W., A.J. Danylchuk, J.M. Chapman, L.F. Gutowsky, and S.J. Cooke. 2017. Best practices for catchand-release recreational fisheries - angling tools and tactics. Fisheries Research 186: 693-705. https://doi.org/10. 1016/j.fishres.2016.04.018

Cerdà, M., J. Alós, M. Palmer, A.M. Grau, and F. Riera. 2010. Managing recreational fisheries through gear restrictions: the case of limiting hook size in the recreational fishery from the Balearic Islands (NW Mediterranean). Fisheries Research 101: 146-155. https://doi.org/10.1016/j.fish res.2009.09.016

Congdon, J.D., A.E. Dunham, and R.V.L. Sels. 1994. Demographics of common snapping turtles (Chelydra serpenti$n a)$ : implications for conservation and management of long-lived organisms. American Zoologist 34: 397-408. https://doi.org/10.1093/icb/34.3.397

Cook, K.V., R.J. Lennox, S.G. Hinch, and S.J. Cooke. 2015. Fish out of water: how much air is too much? Fisheries 40: 452-461. https://doi.org/10.1080/03632415.2015.1074570

Cooke, S.J., and I.G. Cowx. 2004. The role of recreational fishing in global fish crises. BioScience 54: 857-859. https: //doi.org/10.1641/0006-3568(2004)054[0857:TRORFI]2. $0 . \mathrm{CO} ; 2$

Cooke, S.J., and C.D. Suski. 2004. Are circle hooks an effective tool for conserving marine and freshwater recreational catch-and-release fisheries? Aquatic Conservation: Marine and Freshwater Ecosystems 14: 299-326. https://doi.org/ 10.1002/aqc.614

Craig, J.M., D.A. Mifsud, A.S. Briggs, J. Boase, and G. Kennedy. 2015. Mudpuppy (Necturus maculosus maculosus) spatial distribution, breeding water depth, and use of artificial spawning habitat in the Detroit River. Herpetological Conservation and Biology 10: 926-934.

Deroba, J.J., M.J. Hansen, N.A. Nate, and J.M. Hennessy. 2007. Temporal profiles of Walleye angling effort, harvest rate, and harvest in Northern Wisconsin Lakes. North American Journal of Fisheries Management 27: 717-727. https: //doi.org/10.1577/M06-125.1

Gans, C., and R.A. Nussbaum. 1992. The mudpuppy. Pages 108-143 in Vertebrates: a Laboratory Text. Edited by N.K. Wessels and E.M. Center. Jones and Bartlett Learning, Burlington, Massachusetts, USA.

Harding, J.H., and D.A. Mifsud. 2017. Amphibians and Reptiles of the Great Lakes Region. University of Michigan Press, Ann Arbor, Michigan, USA.

Hühn, D., and R. Arlinghaus. 2011. Determinants of hooking mortality in freshwater recreational fisheries: a quantitative meta-analysis. American Fisheries Society Symposium 75: 141-170.
Matson, T.O. 1998. Evidence for home ranges in mudpuppies and implications for impacts due to episodic applications of the lampricide TFM. Pages 278-287 in Status and Conservation of Midwestern Amphibians. Edited by M.J. Lannoo. University of Iowa Press, Iowa City, Iowa, USA.

Matson, T.O. 2005. Necturus maculosus. Pages 870-871 in Amphibian Declines: the Conservation Status of United States Species. Edited by M.J. Lannoo. University of California Press, Berkeley, California, USA.

McDaniel, T.V., P.A. Martin, G.C. Barrett, K. Hughes, A.D. Gendron, L. Shirose, and C.A. Bishop. 2009. Relative abundance, age structure, and body size in mudpuppy populations in southwestern Ontario. Journal of Great Lakes Research 35: 182-189. https://doi.org/10.1016/j.jglr.2008. 12.009

Mifsud, D.A. 2014. A status assessment and review of the herpetofauna within the Saginaw Bay of Lake Huron. Journal of Great Lakes Research 40: 183-191. https://doi.org/10. 1016/j.jglr.2013.09.017

Muoneke, M.I., and W.M. Childress. 1994. Hooking mortality: a review for recreational fisheries. Reviews in Fisheries Science 2: 123-156. https://doi.org/10.1080/106412 69409388555

Pope K., C. Chizinski, C. Wiley, and D. Martin. 2016. Influence of anglers' specializations on catch, harvest, and bycatch of targeted taxa. Fisheries Research 183: 128-137. https://doi.org/10.1016/j.fishres.2016.05.025

R Core Team. 2017. R: A language and environment for statistical computing. R Foundation for Statistical Computing, Vienna, Austria

Raby, G.D., A.H. Colotelo, G. Blouin-Demers, and S.J. Cooke. 2011. Freshwater commercial bycatch: an understated conservation problem. BioScience 61: 271-280. https://doi.org/10.1525/bio.2011.61.4.7

Sales, G., B.B. Giffoni, F.N. Fiedler, V.G. Azevedo, J.E. Kotas, Y. Swimmer, and L. Bugoni. 2010. Circle hook effectiveness for the mitigation of sea turtle bycatch and capture of target species in a Brazilian pelagic longline fishery. Aquatic Conservation: Marine and Freshwater Ecosystems 20: 428-436. https://doi.org/10.1002/aqc.1106

SARA (Species at Risk Act) Registry. 2018. Species profile, Mudpuppy. Accessed 16 May 2018. http://sararegistry.gc. $\mathrm{ca} /$ species/speciesDetails_e.cfm?sid=629\# ot 18 .

Schill, D.J., and R.L. Scarpella. 1997. Barbed hook restrictions in catch-and-release trout fisheries: a social issue. North American Journal of Fisheries Management 17: 873881. https://doi.org/10.1577/1548-8675(1997)017<0873: BHRICA $>2.3 . \mathrm{CO} ; 2$

Serafy, J.E., S.J. Cooke, G.A. Diaz, J.E. Graves, M. Hall, M. Shivji, and Y. Swimmer. 2012. Circle hooks in commercial, recreational, and artisanal fisheries: research status and needs for improved conservation and management. Bulletin of Marine Science 88: 371-391. https://doi.org/ 10.5343/bms.2012.1038

Shoop, C.R., and G.E. Gunning. 1967. Seasonal activity and movements of Necturus in Louisiana. Copeia 1967: 732737. https://doi.org/10.2307/1441882

Silva, V.M.F., and R.C. Best. 1996. Freshwater dolphin/fisheries interaction in the Central Amazon (Brazil). Amazoniana 14: 165-175.

Stoot, L.J., N.A. Cairns, G. Blouin-Demers, and S.J. Cooke. 2013. Physiological disturbances and behavioural impairment associated with the incidental capture of freshwater turtles in a commercial fyke-net fishery. Endangered 
Species Research 21: 3-23. https://doi.org/10.3354/esr 00504

Tufts, B.L., J. Holden, and M. DeMille. 2015. Benefits arising from sustainable use of North America's fishery resources: economic and conservation impacts of recreational angling. International Journal of Environmental Studies 72: 850-868. https://doi.org/10.1080/00207233.2015.10 22987

Twardek, W.M., R.J. Lennox, M.J. Lawrence, J.M. Logan, P. Szekeres, S.J. Cooke, K. Tremblay, G.E. Morgan, and A.J. Danylchuk. 2018. The postrelease survival of Wall- eyes following ice-angling on Lake Nipissing, Ontario. North American Journal of Fisheries Management 38: 159 169. https://doi.org/10.1002/nafm.10009

Weltersbach, M.S., K. Ferter, F. Sambraus, and H.V. Strehlow. 2016. Hook shedding and post-release fate of deep-hooked European eel. Biological Conservation 199: 16-24. https://doi.org/10.1016/j.biocon.2016.04.015

Received 31 January 2018

Accepted 3 April 2018 